\title{
Dermatoglyphics Pattern on Breast Cancer Patients in Dharmais Cancer Hospital
}

\author{
Faras Qodriyyah Sani, ${ }^{1}$ Mirfat, ${ }^{2}$ Iskandar ${ }^{3}$ \\ ${ }^{1}$ Medical Undergraduate Study Program, Faculty of Medicine, Universitas YARSI, Jakarta, Indonesia, \\ ${ }^{2}$ Department of Biology, Faculty of Medicine, Universitas YARSI, Jakarta, Indonesia, \\ ${ }^{3}$ Department of Surgical Oncology, Dharmais Cancer Hospital, Jakarta, Indonesia
}

\begin{abstract}
Dermatoglyphics is a study of the epidermal ridge in fingers, palms, soles, toes, and formed under genetic control at the beginning of the development of the fetus around 6-7 weeks and continues until 20-21 weeks. The development of the breast begins in a 6-week-old fetus in the epidermis and at the bottom of the mesenchyme. The development of the finger ridges and breast occurs at six weeks of gestation, and the abnormal genomes can be detected at this period and observed through dermatoglyphics. The purpose of this study was to determine the dermatoglyphic patterns of breast cancer patients in Dharmais Cancer Hospital from 12 December 2018 to 1 January 2019. The study was a descriptive study with a purposive sampling method for the determination of the sample. The quantitative data collected using questionnaires while the prints of dermatoglyphic patterns were from the fingertips of the respondent. From 100 respondents, the left-hand fingers and right-hand fingers dominated by radial loop pattern with the most significant percentage on the middle finger $62 \%$ and $77 \%$, respectively. While the ring finger dominated by the plain whorl pattern $43 \%$. In conclusion, the dermatoglyphics pattern on breast cancer patients in Dharmais Cancer Hospital dominated by a radial loop pattern.
\end{abstract}

Key words: Breast cancer, dermatoglyphics, Dharmais Cancer Hospital

\section{Pola Dermatoglifi Tangan Pasien Kanker Payudara di Rumah Sakit Kanker Dharmais}

\begin{abstract}
Abstrak
Dermatoglifi merupakan ilmu yang mempelajari tentang pola sulur pada jari, telapak tangan, telapak kaki, dan jari kaki yang terbentuk di bawah kontrol genetik pada awal perkembangan usia janin sekitar 6-7 minggu serta terus berkembang sampai usia 20-21 minggu. Perkembangan payudara dimulai pada janin berusia 6 minggu dalam bentuk gumpalan padat yang berada di epidermis dan di bagian bawah mesenkim. Perkembangan sulur dermal dan payudara terjadi pada usia kehamilan enam minggu dan genom tidak abnormal dapat dideteksi pada periode ini dan dapat teramati melalui dermatoglifi. Tujuan penelitian ini mengetahui pola dermatoglifi pada pasien kanker payudara di Rumah Sakit Kanker Dharmais dari tanggal 12 Desember 2018 hingga 1 Januari 2019. Penelitian ini merupakan studi deskriptif dengan metode purposive sampling untuk penentuan sampel. Data kuantitatif diperoleh dengan menggunakan kuesioner, sedangkan cetakan pola dermatoglifi berasal dari ujung jari tangan responden. Dari 100 responden, jari tangan kiri dan jari tangan kanan didominasi oleh pola radial loop dengan persentase terbesar pada jari tengah sebesar 62\% dan 77\% masing-masing. Sementara jari manis didominasi oleh pola plain whorl sebesar $43 \%$. Simpulan, pola dermatoglifi pada pasien kanker payudara di Rumah Sakit Kanker Dharmais didominasi oleh pola radial loop.
\end{abstract}

Kata kunci: Dermatoglifi, kanker payudara, Rumah Sakit Kanker Dharmais 


\section{Introduction}

Dermatoglyphics is a study of the epidermal ridge in fingers, palms, soles, and toes. ${ }^{1-7}$ Dermatoglyphics was formed under genetic controlat thebeginning of pregnancy development around 6-7 weeks in the form of volar pads and continues to develop and then will form on the surface of the skin until the age of 20-21 weeks, but can be affected by environmental factors during the first trimester of pregnancy. ${ }^{1-4}$ This pattern will become permanent after four months of pregnancy and will not change throughout life. ${ }^{8}$

Early development of the breast begins in the 6-week-old fetus in the epidermis and at the bottom of the mesenchyme. The development of the finger ridges was in the form of volar pads and occurred at six weeks of gestation and will reach maximum size at 12-13 weeks of gestation. The genetic information that is in the normal and abnormal genomes can be detected in this period and can be observed through dermatoglyphics. ${ }^{9}$

The dermatoglyphic study used to prove whether specific fingerprint patterns correlate with several diseases. Some diseases reported correlating with fingerprint patterns such as down syndrome, mental retardation, multiple sclerosis, and thalassemia. ${ }^{10}$ Raizada et al. ${ }^{11}$ researched dermatoglyphics to carcinoma breast patients in India to determine whether dermatoglyphics could be used for screening or guide future research for breast cancer. In their research, it found that there were significant dermatoglyphic differences between breast cancer patients and healthy people. Sukre et al. ${ }^{12}$ conducted a similar study, the results of their study showed that dermatoglyphics among breast cancer patients with healthy people were different too. The result of their research, it was stated that there was a significant difference percentage in finger pattern found in breast cancer patients where the whorl pattern on the right-hand thumb was $52 \%$ while the whorl pattern on the right hand of healthy people was $38 \%$.

Breast cancer is a malignancy in breast tissue that can originate from the ductal epithelium or lobule. ${ }^{13}$ Breast cancer generally occurs in women, at least about one-third of women who have cancer is breast cancer. ${ }^{14}$

Based on estimated data from the International Agency for Research on Cancer (IARC) of the World Health Organization (WHO) in 2012, breast cancer was the highest incidence of cancer worldwide in women as many as $1,671,149$ (25\% of all incident breast cancer cases), while the death is $521.907 .{ }^{15}$ In the Asian continent, breast cancer was also the highest incidence of breast cancer in women at 650,983 (21\%) of the female population, while the mortality rate is second only to lung cancer, which is 231,013 (13\%) of female residents. ${ }^{16}$ In the Indonesian region, according to 2014 Country Profiles WHO estimates, the incidence of breast cancer in women was first in 48,988 (30,5\%) of the total population, whereas the highest mortality rate is $19,750(21.4 \%){ }^{17}$

Breast cancer is a genetic disease that may show a typical dermatoglyphic pattern in the risk group. Breast cancer is most common in women from the age group of 45-55 years and dermatoglyphics can help identify an increased risk of developing breast cancer in women. Dermatoglyphic can also be the earliest diagnostic tool for breast cancer..$^{12}$ The study of the dermatoglyphic pattern is simple, does not need repetition, does not require much time, is not invasive, and inexpensive..$^{18}$ The purpose of this study was to determine the dermatoglyphic pattern on breast cancer patients at Dharmais Cancer Hospital.

\section{Methods}

This study using descriptive study and determination of sample was using purposive sampling. The quantitative data obtained from questionnaires and the results dermatoglyphic patterns used printed fingertips of the respondent. This study was carried out on 12 December 2018-1 January 2019 at Dharmais Cancer Hospital, Jakarta. The sample was 100 respondents, and the data collected after the subject agreed and signed informed consent. The target population in this study were breast cancer patients who were seeking treatment at Dharmais Cancer Hospital. The samples used in this study were respondents who met the criteria, which were breast cancer patients who had upper limbs, mainly hands without any deformity on one of the fingers. They were willing and filled out the research questionnaire and present it at the time of sampling. The type of fingerprint pattern in this study divided into eight categories, plain whorl, double loop whorl, central pocket loop whorl, accidental whorl, plain arch, tented arch, radial loop, and ulnar loop. The type of data used in this study is quantitative data from the results of the questionnaire. Cross-sectional data analysis used descriptive statistical techniques that were 
processed using SPSS version 22.0.

This study had approved by the Health Research Ethics Committee of the Faculty of Medicine of the University of YARSI by ethical approval letter number: 230/KEP-UY/BIA/ IX/2018.

\section{Results}

The following is a data distribution of fingerprint patterns on the right and left hand is in Table 1.

Based on Table 1, the frequency distribution type of fingerprint pattern of breast cancer patients consisted of radial loop 53.8\%, plain whorl $23.2 \%$, double loop whorl $8.3 \%$, plain arch $5.7 \%$, central pocket loop whorl $3.7 \%$, ulnar loop $3.6 \%$, tented arch $1.0 \%$, and accidental whorl $0.7 \%$. The left-hand fingers dominated by a radial loop pattern (Figure a) with the most significant percentage on the left middle finger, which was
$62 \%$. The right hand dominated by a radial loop with the highest found on the right middle finger that was $77 \%$ while the ring finger dominated by the plain whorl (Figure b) pattern that was $43 \%$.

In this study, respondents were grouped based on data on age, gender, ethnicity of the father, and ethnic group. The following is the distribution of respondent data based on demographic data in Table 2.

Based on Table 2, breast cancer patients were all females (100\%) and over 40 years old (88\%). Based on the ethnic characteristics of parents, the respondents in this study dominated by Javanese parents.

\section{Discussion}

The dermatoglyphics pattern of breast cancer patients in Dharmais Cancer Hospital dominated by radial loop patterns. Madhavi et al..$^{18}$ conducted

Table 1 Frequency Distribution of Finger Ridges

\begin{tabular}{|c|c|c|c|c|c|c|c|c|c|c|c|}
\hline \multirow[b]{3}{*}{ Finger Ridges } & \multicolumn{10}{|c|}{ Frequency of Finger Ridges } & \multirow[b]{3}{*}{$\begin{array}{c}\text { Total } \\
\text { (\%) }\end{array}$} \\
\hline & \multicolumn{5}{|c|}{ Left Hand $(n=100)$} & \multicolumn{5}{|c|}{ Right Hand $(\mathrm{n}=100)$} & \\
\hline & है & 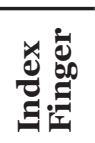 & 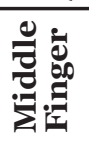 & 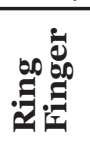 & 总 & है & 总 & 总 & 离 & 总离 & \\
\hline Plain whorl & 24 & 23 & 15 & 33 & 15 & 25 & 24 & 12 & 43 & 18 & 23.2 \\
\hline Double loop whorl & 20 & 8 & 6 & 3 & 8 & 19 & 6 & 3 & 6 & 4 & 8.3 \\
\hline Central pocket loop whorl & 1 & 5 & 4 & 4 & 4 & 1 & 6 & o & 6 & 6 & 3.7 \\
\hline Plain arch & 7 & 9 & 7 & 5 & 9 & 3 & 6 & 4 & 5 & 2 & $5 \cdot 7$ \\
\hline Tented arch & o & 2 & 1 & 2 & 2 & 0 & 1 & 1 & o & 1 & 1.0 \\
\hline Radial loop & 44 & 38 & 62 & 52 & 59 & 51 & 50 & 77 & 39 & 66 & 53.8 \\
\hline Ulnar loop & 2 & 13 & 5 & 1 & 2 & 1 & 6 & 3 & 1 & 2 & 3.6 \\
\hline Accidental whorl & 2 & 2 & $\mathrm{o}$ & o & 1 & o & 1 & o & o & 1 & 0.7 \\
\hline
\end{tabular}

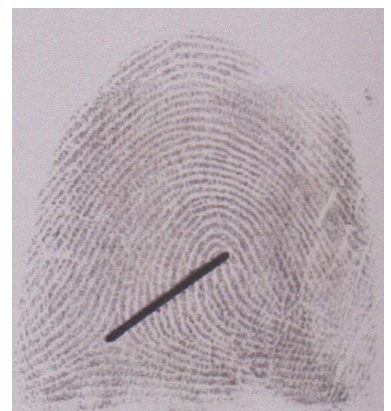

(a)

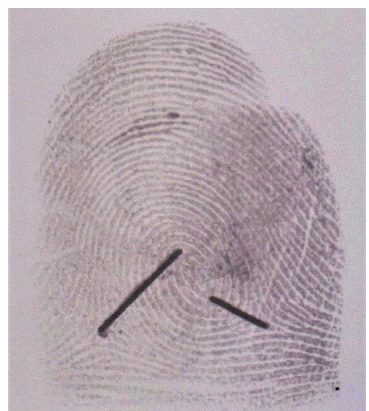

(b)

Figure (a) Radial Loop Pattern and (b) Plain Whorl Pattern on Right Hand Breast Cancer Patients in Dharmais Cancer Hospital 
Table 2 Demographics based on Age, Father and Mother Tribe

\begin{tabular}{lc}
\hline Categories & $\begin{array}{c}\text { Breast Cancer } \\
\mathbf{n = 1 0 0}(\%)\end{array}$ \\
\hline Age (years) & 12 \\
$\leq 40$ & 88 \\
$>40$ & \\
Gender & 100 \\
Women & \\
Father's tribe & 28 \\
Sunda & 39 \\
Jawa & 11 \\
Betawi & 16 \\
Sumatera & 2 \\
Sulawesi & 3 \\
Kalimantan & 1 \\
Flores & \\
Mother's tribe & \\
Sunda & 29 \\
Jawa & 36 \\
Betawi & 11 \\
Sumatera & 17 \\
Sulawesi & 2 \\
Kalimantan & 4 \\
Flores & 1 \\
\hline
\end{tabular}

a study of fingerprint patterns between breast cancer patients and non-cancer people in India. The results of their study showed that breast cancer patients' right hand were dominated by the whorl pattern, which was equal to $53.2 \%$, whereas, in healthy people, the whorl pattern was $15.8 \%$. While in the left-hand, breast cancer patients dominated by the whorl pattern, which was equal to $56 \%$, and in healthy people, the whorl pattern was only $16.2 \%$. The results of their study did not specifically mention which whorl pattern in breast cancer patients. Lavanya et al. ${ }^{9}$ also conducted a similar study in India. The results of the study showed that breast cancer patients dominated by the whorl pattern, which equal to $53.3 \%$ and in healthy people $23.3 \%$. Therefore, based on the results of the above studies, the finger pattern of breast cancer patients in this study and India had different dominance. Radial loop patterns dominated the breast cancer dermatoglyphics in this study, while whorl patterns dominated the fingerprint pattern of breast cancer in India. The differences in the results of these studies may differ due to environmental, ethnic, and racial influences. ${ }^{14}$

This study found that breast cancer patients were all female (100\%) and over 40 years old (88\%). According to YKPI, ${ }^{19}$ being a woman and increasing age would increase the incidence of breast cancer. ${ }^{20}$ Breast cancer is cancer that is more common in women..$^{21}$ Women are 100 times more at risk of breast cancer than men. ${ }^{22}$ At the age of $\geq 40$ years, the hormone progesterone cannot be produced in sufficient quantities so that the production of the hormone estrogen cannot be resisted. ${ }^{23}$ These theories support the result of this study.

Based on the ethnic characteristics of the respondent's parents, the respondents in this study dominated by parents who were Javanese. Pusat Data dan Statistik Pendidikan dan Kebudayaan (PDSPK) stated that is most tribes in Indonesia are Javanese. ${ }^{24}$

Purbasari and Sumadji ${ }^{25}$ researched on fingerprint pattern in ethnic groups. In their research, it mentioned that people who were Javanese and female sex dominated by a loop pattern of $62.38 \%$.

\section{Conclusion}

The dermatoglyphic pattern of breast cancer patients at Dharmais Cancer Hospital was a radial loop pattern.

\section{Conflict of Interest}

All authors stated that there was no conflict of interest in this article.

\section{Acknowledgments}

Thanks to the doctors, nurses, respondents, staff at Dharmais Cancer Hospital who have helped the author for the implementation of this study.

\section{References}

1. Abilasha S, Harisudha R, Janaki CS. Dermatoglyphics: a predictor tool to analyze the occurrence of breast cancer. IJMRHS. 2013;3(1):28-31.

2. Pakhale SV, Borole BS, Doshi MA, More VP. Study of the fingertip pattern as a tool for the identification of the dermatoglyphic trait in bronchial asthma. J Clin Diagn Res. 2012;6(8):1397-400.

3. Raizada A, Johri V, Ramnath T, Chowdhary D, Garg R. A cross-sectional study on the palmar dermatoglyphics in relation to 
carcinoma breast patients. J Clin Diagn Res. 2013;7(4):609-12.

4. Sharma A, Sood V, Singh P, Sharma A. Dermatoglyphics: a review on fingerprints and their changing trends of use. CHRISMED J Health Res. 2018;5(3):167-72.

5. Singh S, Khurana AK, Harode HA, Tripathi A, Pakhare A, Chaware P. Study of fingerprint patterns to evaluate the role of dermatoglyphics in early detection of bronchial asthma. J Nat Sci Biol Med. 2016;7(1):43-6.

6. Vaidya P, Mahale S, Badade P, Warang A, Kale S, Kalekar L. Dermatoglyphicsin periodontics: an assessment of the relationship between fingerprints and periodontal status - a crosssectional observation study. Indian J Dent Res. 2017;28(6):637-41.

7. Kc S, Maharjan N, Adhikari N, Shrestha P. Qualitative analysis of primary fingerprint pattern in different blood group and gender in Nepalese. Anat Res Int. 2018;2018:2848974.

8. Singh A, Gupta R, Zaidi SHH, Singh A. Dermatoglyphics: a brief review. Int $\mathrm{J}$ Adv Integr Med Sci. 2016;1(3):111-5.

9. Lavanya J, Saraswathi P, Vijayakumar J, Prathap S. Analysis of dematoglyphic traits in patients with breast cancer. $J$ Pharm Biomed Sci. 2012;23(24):1-5.

10. Jamalian M, Mesri M, Vishteh HRK, Solhi H, Salehpour R. Fingerprints: a simple method for screening hemophilic patients. Bangladesh Med Res Counc Bull. 2014;40(2):85-8.

11. Raizada A, Johri V, Ramnath T, Chowdhary DS, Garg RP. A cross-sectional study on the palmar dermatoglyphics in relation to carcinoma breast patients. J Clin Diagn Res. 2013 Apr;7(4):609-12.

12. Sukre SB, Laeeque M, Mahajan A, Shewale SN. Dermatoglyphics in the identification of women either with or at risk of breast cancer. IJBMS. 2012;3(5):160-5.

13. Moore KL, Dalley AF. Anatomi berorientasi klinis. $5^{\text {th }}$ Edition. Jilid 1. Jakarta: Penerbit Erlangga; 2013.

14. Sariri E, Kashanian M, Vahdat M, Yari S. Comparison of the dermatoglyphics characteristics of women with and without breast cancer. Eur J Obstet Gynecol Reprod Biol. 2012;160(2):201-4.

15. International Agency for Research on Cancer (IARC) World Health Organization (WHO).
Cancer fact sheets: breast cancer [Internet]. 2016 [cited 2018 September 25]. Available from: https://gco.iarc.fr/today/data/pdf/ fact-sheets/cancers/cancer-fact-sheets-15. pdf

16. International Agency for Research on Cancer (IARC) World Health Organization (WHO). Population fact sheets: Asia [Internet]. 2012 [cited 2018 September 25]. Available from: https://documentcloud.adobe.com/link/tr ack/?pageNum =1\&uri=urn\%3Aaaid\%3As cds\%3AUS\%3Aaob12e73-ac7a-45ea-ae11ceo6671e5f 39 .

17. World Health Organization (WHO). Cancer country profiles: Indonesia [Internet]. 2014 [cited 2018 September 25]. Available from: https://www.who.int/cancer/countryprofiles/idn_en.pdf..

18. Madhavi D, Dorairaj S, Dorairaj SSJ, Kommuru H. Dermatoglyphic study in breast carcinoma patients. IJSR. 2016;5(10):83740.

19. Yayasan Kanker Payudara Indonesia (YKPI). Tentang kanker payudara: penjelasan umum [Internet]. 2015 [cited 2019 January 9]. Available from: https://pitapink-ykpi.or.id/ tentang-kanker-payudara/.

20. Sjamsuhidajat R, Prasetyono TOH, Rudiman R, Riwanto I, Tahalele P. Buku ajar ilmu bedah. $4^{\text {th }}$ Edition. Volume 2. Jakarta: EGC; 2017.

21. Kumar V, Abbas AK, Aster JC, Ham M, Saraswati M. Buku ajar patologi Robbins. $9^{\text {th }}$ Edition. Philadelphia: Saunders; 2015.

22. Sihombing M, Sapardin AN. Faktor risiko tumor payudara pada perempuan umur 2565 tahun di lima kelurahan Kecamatan Bogor Tengah. Kespro. 2014;5(3):175-84.

23. Irawan ED, Wahyuningsih, Fatimah FS. Hubungan antara usia menarche dan riwayat keluarga dengan kejadian kanker payudara pada wanita usia 35-60 tahun di Ruang Kemoterapi RSUD Panembahan Senopati Bantul Yogyakarta [undergraduate thesis]. Yogyakarta: Universitas Alma Ata; 2017 [cited 2019 January 12]. Available from: http://elibrary.almaata.ac.id/707/1/ naspub\%2oeko.pdf.

24. Pusat Data dan Statistik Pendidikan dan Kebudayaan (PDSPK) Kementerian Pendidikan dan Kebudayaan Republik Indonesia. Analisis kearifan lokal ditinjau dari keragaman budaya [Internet]. Jakarta: 
PDSPK Kementerian Pendidikan dan Kebudayaan Republik Indonesia; 2016 [cited 2019 January 13]. Available from: http:// publikasi.data.kemdikbud.go.id/uploadDir/ isi_F9B 76ECA-FD28-4D62-BCAE-
E89FEB2D2EDB_.pdf.

25. Purbasari K, Sumadji AR. Variasi pola sidik jari mahasiswa berbagai suku bangsa di Kota Madiun. Florea. 2017;4(2):47-54. 